\title{
Recent volcanism, tectonics and plate kinematics near the junction of the African, Arabian and Anatolian plates in the eastern Mediterranean
}

\author{
M. Tekin Yürür ${ }^{\mathrm{a}, *}$, Jean Chorowicz ${ }^{\mathrm{b}}$ \\ ${ }^{a}$ Hacettepe University, Department of Engineering Geology, 06532, Beytepe, Ankara, Turkey \\ ${ }^{\mathrm{b}}$ Université Paris 6, Géotectonique, Case 129, LGGST, 4 place Jussieu, 75252 Paris, France
}

\begin{abstract}
In the Eastern Mediterranean, plate convergence occurs between Africa-Arabia and Anatolia. The Africa/Arabia motion is a strike-slip displacement along the Dead Sea fault. The Africa/Anatolia motion is taken up by subduction south of Cyprus. The convergence between Arabia and Anatolia is taken up along the East Anatolian fault. The analysis of the regional fault surfaces reveals the presence of two major tectonic phases that affected southeastern Turkey near the junction of these three plates. The older deformations are related to a $\mathrm{N}-\mathrm{S}$ compression. The more recent movements are directed mainly westward and associated with strike-slip and extension tectonics. Near the triple junction since $2 \mathrm{Ma}$, a fissure volcanism produced tholeiite followed by alkali basalt along the Amanos fault, the northern end segment of the Dead Sea Fault. In addition, reconstruction of rigid-plate kinematics between Arabia, Africa and Anatolia using recent plate motion parameters and space geodesy data suggest for the East Anatolian fault a slip rate of $7.8-9 \mathrm{~mm} /$ year. The maximum finite displacement recognised for this structure being around $15 \mathrm{~km}$, we have obtained $1.9 \mathrm{Ma}$ as the maximum age for the fault formation. The volcanic, tectonic and kinematic data converge to propose a ca. $2 \mathrm{Ma}$ age for the change of local tectonic regime in the junction area. The structural mapping, the geometry of the fractures used by the magma to reach the surface and the presence of alkali basalt of mantle source suggest that the deformation along the northern end of the Dead Sea transform, i.e., the Amanos fault, was modified by the formation of the East Anatolian fault zone. In this region, apparition of the East Anatolian fault accommodating westward motion of the Anatolian plate resulted in oblique-slip tension along the Amanos segment of the Dead Sea transform, giving rise to a fissure-fed, mantle-derived alkaline volcanism at ca. $2 \mathrm{Ma}$, which lasted until recent times (0.4 Ma). (C) 1998 Elsevier Science B.V. All rights reserved.
\end{abstract}

Keywords: neotectonics; fault movements; alkaline volcanism; plate kinematics; SE Turkey; East Anatolian fault

\section{Introduction}

The present-day geodynamics of the Eastern Mediterranean results from the relative motion between three continental plates, namely: Eurasia,

\footnotetext{
* Corresponding author. Tel.: +90-312-235-25-42; Fax: +90312-299-21-36; E-mail: tekin@jeo.hun.edu.tr
}

Africa and Arabia (McKenzie, 1970, 1972; Dewey et al., 1973; Sengör et al., 1985). During the middle Miocene, Arabia was separated from Africa along the left-lateral Dead Sea fault zone (e.g., Le Pichon and Gaulier, 1988). In the middle to late Miocene time interval, the northern border of Arabia entered into collision with the southern margin of Eurasia (e.g., Perinçek, 1979), forming the Bitlis Thrust Zone. 
Contemporaneously with this collisional event (ca. 13 Ma, e.g., Le Pichon and Gaulier, 1988) or later (Pliocene, 5 Ma, Barka and Kadinsky-Cade, 1988;
Jackson and McKenzie, 1988), part of the hitherto shortened and thickened Eurasian lithosphere began to move west, towards the Hellenic subduction zone

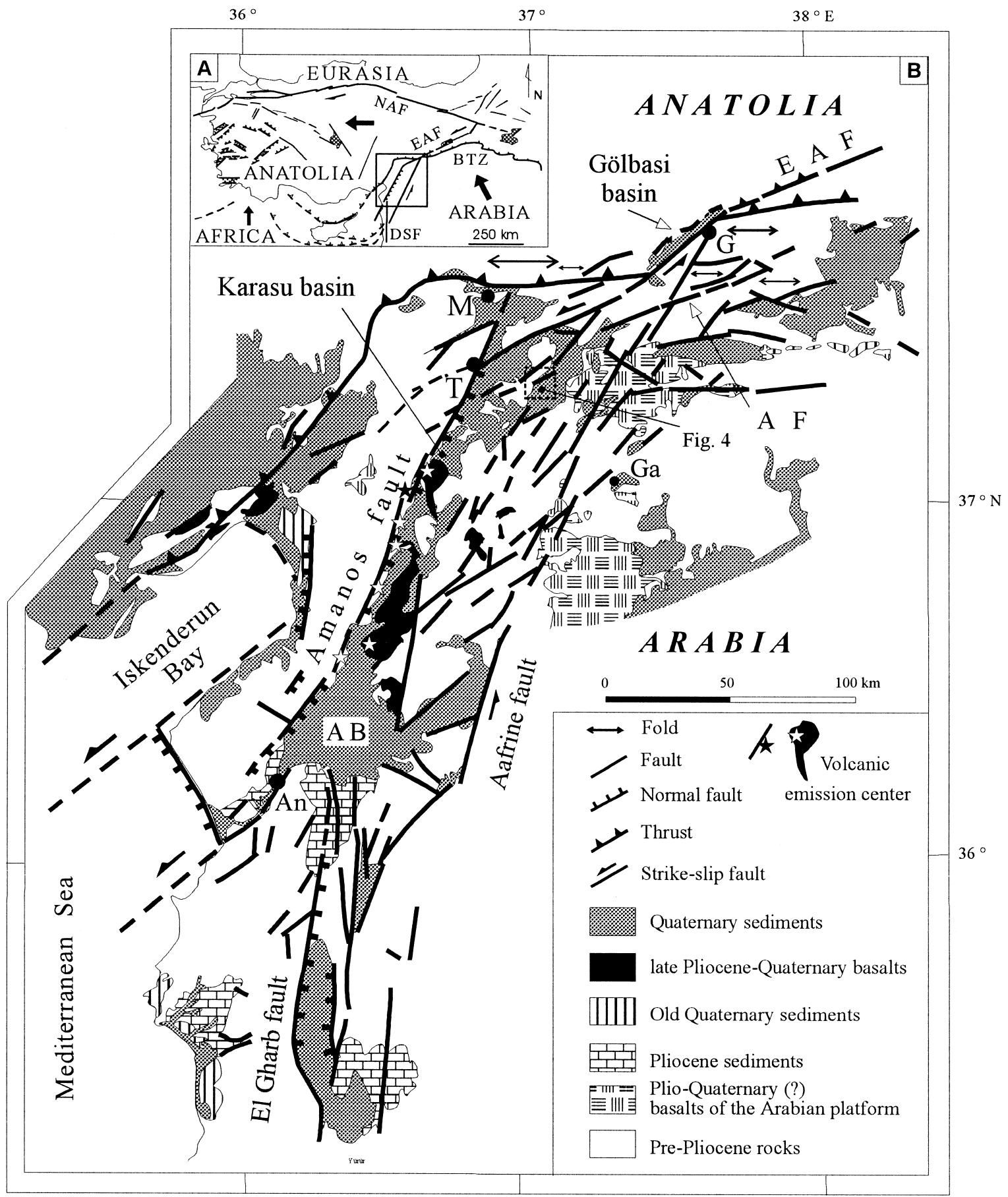


where the northern African oceanic slab is underplated (e.g., McKenzie, 1972; Le Pichon and Angelier, 1979). The lateral extrusion of this lithospheric mass, the Anatolian block, is accommodated by two transform faults, the North Anatolian fault (McKenzie, 1972; Sengör, 1979; Jackson and McKenzie, 1984) and the East Anatolian fault (Arpat and Saroglu, 1972, 1975; Seymen and Aydin, 1972; McKenzie, 1976). Recent space geodetic data analysis (Oral et al., 1994; Le Pichon et al., 1995) has confirmed the westerly motion of the Anatolian block.

For several workers (McKenzie, 1972; Sengör et al., 1985; Gülen et al., 1987), the junction between Anatolia, Arabia and Africa is located near Maras, SE Turkey (Fig. 1). There are different models because the regional deformation is of polyphased character, attested by the presence of late Neogene angular unconformities (Kelling et al., 1987; Yilmaz et al., 1988; Karig and Kozlu, 1990), and the fracturing pattern near Maras is relatively complex (Fig. 1). According to McKenzie (1976), the East Anatolian fault zone continues west of the junction and is linked with the Cyprean Arc, along which the Africa/Anatolia convergence is taken up by means of thrusting and strike-slip faulting (Fig. 1a). Field work and seismic profile analyses of Perinçek and Çemen (1990) suggest that the East Anatolian and the Dead Sea fault segments in Turkey may be considered as one broad fault system. Along the Amanos fault (Fig. 1), recent basaltic rocks, dated at 2-0.4 Ma (Çapan et al., 1987), are vertically offset for several hundred meters (Arpat and Saroglu, 1972). Some geologists expressed the thesis that the northernmost segment of the Dead Sea fault is located east of the Amanos fault, and terminates against the Taurus Range near Gölbasi (Çapan et al., 1987; Perinçek and Çemen, 1990). The area was also studied by Lyberis et al. (1992) and Chorowicz et al.
(1995), with the authors, by means of satellite imagery and microtectonic analysis. They presented some characteristics of the regional stress pattern on the basis of stress tensors computed using fault striation data.

In this paper, we make use of the structural data obtained in the field (Yürür, 1992). The data consist of displacement vectors observed as slickensides on fault planes. Existing geological maps and our satellite image and field analyses are used to produce a fracture map near the Maras junction. We then present data concerning the recent volcanism studied in detail by Çapan et al. (1987). This section will help to confirm the lithospheric nature of the Amanos fault and precise the chronology of the change of tectonic regime. Analysis of the kinematics based on current plate motions and space geodesy data will help to establish the present-day plate motions with which we have computed the initiation age of the East Anatolian fault. These multi-source data taken together suggest that the study area has experienced a change of tectonic regime during which a considerably rapid fissure volcanism was generated along the Amanos fault. This paper shows how multi-source data can help in understanding and dating the relationships between a local tectonic change linked with more general plate tectonics, and the occurrence of volcanism.

\section{Structural data}

We essentially have measured slickensides and extension veins along either the major fault planes or along nearby faults with planes subparallel to that of the major fault, assuming that subparallel planes close to each other are affected by the same tectonic regime and bear geometrically and mechanically similar tectoglyphes. Some fault planes display evidences of successive deformations. A good field

\footnotetext{
Fig. 1. Structure of the studied area. (A) Major neotectonic structures and plate configuration in and around Anatolia. BTZ: Bitlis Thrust Zone; DSF: Dead Sea fault; EAF: East Anatolian fault; NAF: North Anatolian fault; T: Türkoglu. Arrows are drawn parallel to plate motions relative to Eurasia. (B) Simplified geological map of the area surrounding the Maras Junction, drawn from a $1 / 250000$ scale, false colours, Landsat TM Image, path 174, row 34, acquired on October 22, 1989. We made use of the geological maps of Dubertret (1955, 1962) and Ponicarov (1967) for the Syrian sector, the 1/500 000 scale Adana and Hatay sheets of MTA (1962a,b), Yalçin (1979), Arpat and Saroglu (1975), Muehlberger (1981), Muehlberger and Gordon (1987), Perinçek et al. (1987) and Yilmaz et al. (1988). We also benefited from field observations and satellite image interpretations. AB: Amik basin; An: Antakya; EAF: East Anatolian fault; G: Gölbasi; Ga: Gaziantep; M: Maras.
} 


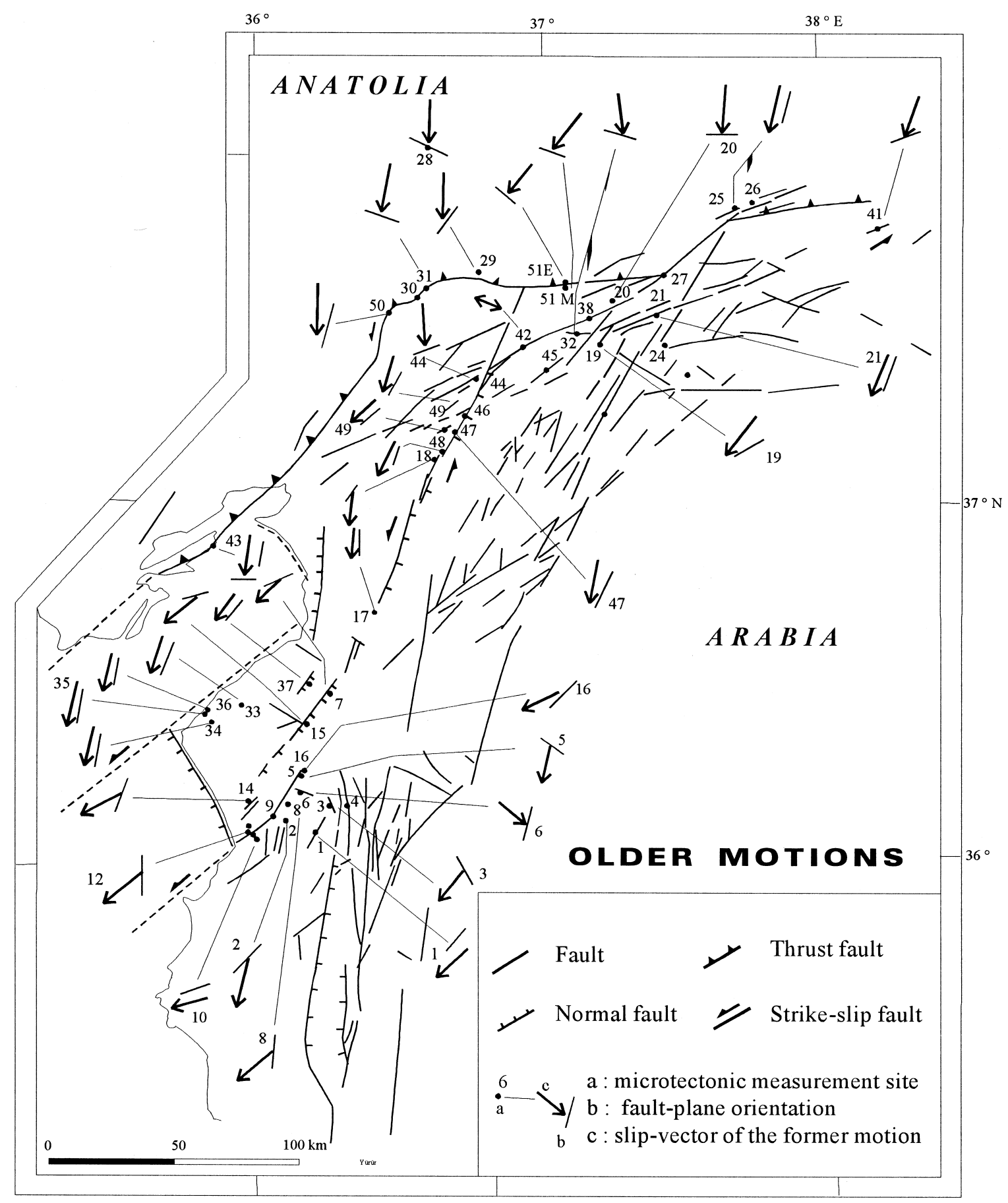

Fig. 2. Map of the 'older' motions observed along the major fault planes. 


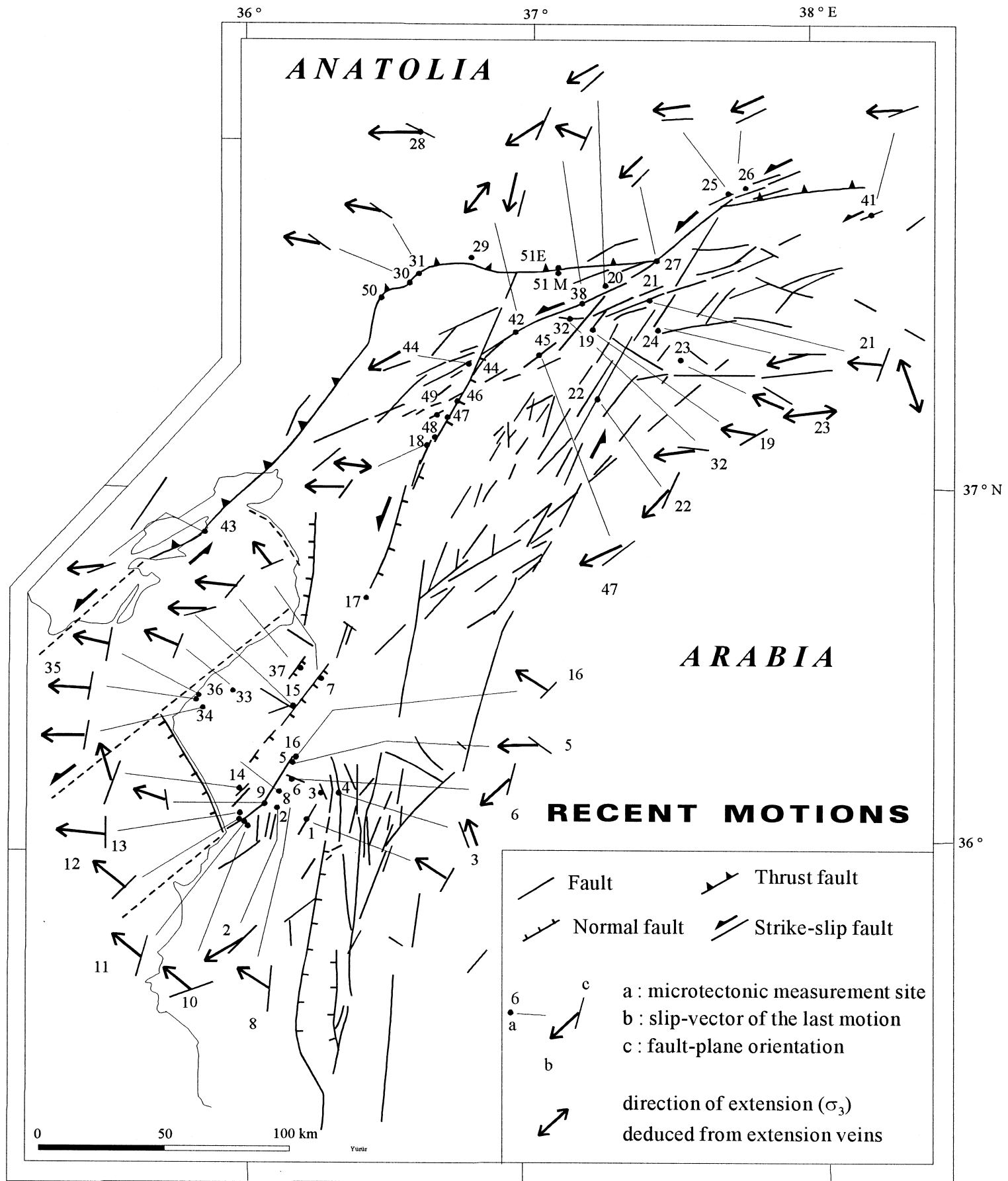

Fig. 3. Map of the 'recent' motions observed along the major fault planes. 
Table 1

Fault lines and slip-vector directions of the successive motions

\begin{tabular}{|c|c|c|c|c|c|c|}
\hline $\begin{array}{c}\text { Station } \\
\text { no. }\end{array}$ & $\begin{array}{l}\text { Main fault } \\
\text { orientation }\end{array}$ & Event 1 & Event 2 & Event 3 & Explanation & $\begin{array}{l}\text { Age of the youngest } \\
\text { rock affected }\end{array}$ \\
\hline 1 & $\mathrm{~N} 030^{\circ}$ & Ll & 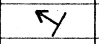 & & LIN (1) & middle Miocene \\
\hline 2 & $-\mathrm{N} 045^{\circ}$ & 1 & $K /$ & & $\mathrm{T} / \mathrm{F}(\mathrm{l})$ & Eocene \\
\hline 3 & $-\mathrm{N} 150^{\circ}$ & & 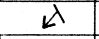 & & & Langhian \\
\hline 5 & $\sim \mathrm{N} 125^{\circ}$ & $\sqrt{2}$ & $\longleftrightarrow$ & & LIN (3) & Langhian \\
\hline 6 & $\sim \mathrm{N} 015^{\circ}$ & $\pm y a$ & $4 b$ & $\diamond^{c}$ & LIN (1)\& F & $\mathrm{a}$ : Eocene b, $\mathrm{c}$ : Langhian \\
\hline 8 & $\sim \mathrm{N} 005^{\circ}$ & $\downarrow$ & Y & & LIN (1) & Eocene $\cap$ middle Miocene \\
\hline 9 & $\mathrm{~N} 172^{\circ}$ & & 4? & & & post-Eocene fault breccia \\
\hline 10 & $\sim \mathrm{N} 070^{\circ}$ & 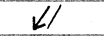 & 5 & & & Ophiolite $\cap$ Eocene \\
\hline 11 & $\mathrm{~N} 016^{\circ}$ & & $\pi_{y}$ & & & Eocene \\
\hline 12 & $-\mathrm{N} 000^{\circ}$ & $\Lambda$ & $\bar{y}$ & & LIN (1) & Eocene early-middle Miocene \\
\hline 13 & $\sim \mathrm{N} 000^{\circ}$ & & $\leftarrow$ & & & Eocene \\
\hline 16 & $\sim \mathrm{N} 045^{\circ}$ & L/ & $\gamma$ & & & middle Miocene \\
\hline 4 & $\sim \mathrm{N} 165^{\circ}$ & & $1 \uparrow$ & & & Pliocene \\
\hline 19 & $\sim \mathrm{N} 060^{\circ}$ & $L$ & 5 & & & post- Eocene mélange \\
\hline 21 & $\sim \mathrm{N} 020^{\circ} *$ & $\downarrow$ & $\widehat{N}$ & $\uparrow \sigma_{3}$ & OEV & Eocene \\
\hline 22 & $\sim \mathrm{N} 025^{\circ} *$ & 4 & & & & Pliocene (?) \\
\hline 23 & $\sim \mathrm{N} 130^{\circ} *$ & रो & 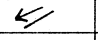 & $\leftrightarrow \sigma_{3}$ & OEV & Miocene - Pliocene (?) \\
\hline 24 & $\sim \mathrm{N} 090^{\circ}$ & & $\longleftarrow$ & & & Miocene \\
\hline 32 & $\sim \mathrm{N} 110^{\circ}, 170^{\circ}$ & $\pi 1$ & $\leftrightarrow$ & & $\mathrm{QF}$ & Quaternary \\
\hline 45 & N $052^{\circ}, 84^{\circ} \mathrm{NW}, 26^{\circ} \mathrm{W}$ & & 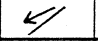 & & $\mathrm{AF}$ & Ophiolites \\
\hline 7 & $-\mathrm{N} 065^{\circ}$ & $\nwarrow$ & 1 & & LIN (1) & Eocene $\cap$ middle Miocene \\
\hline 14 & $-\mathrm{N} 020^{\circ}$ & $\downarrow 1$ & $\pi$ & & & middle Miocene \\
\hline 15 & $-\mathrm{N} 075^{\circ}$ & $E$ & $\leftarrow$ & & LIN (4) & Eocene \\
\hline 33 & $\sim \mathrm{N} 022^{\circ}$ & 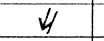 & $r$ & & LIN (4) & Ophiolite $\cap$ Miocene \\
\hline 34 & $\sim \mathrm{N} 010^{\circ}$ & $\downarrow$ & $\leftarrow$ & & FAT & Messinian \\
\hline 35 & $\sim \mathrm{N} 015^{\circ}, 055^{\circ}$ & $\downarrow$ & $\leftarrow$ & & & Pliocene \\
\hline 36 & $\sim N 000^{\circ}$ & $\downarrow$ & 4 & & LIN (1) & Messinian-Pliocene \\
\hline 37 & $-\mathrm{N} 0000^{\circ}, 0+10^{\circ}$ & $W$ & $\leftrightarrow \leftarrow$ & & LIN (5) & Middle Miocene \\
\hline 17 & $\sim \mathrm{N} 000^{\circ}$ & $\downarrow$ & $\downarrow$ & $\sigma_{3}$ & & Cretaceous \\
\hline 18 & $\sim \mathrm{N} 025^{\circ} *$ & $\downarrow$ & $\leftrightarrow$ & $\leftrightarrow \swarrow$ & $\mathrm{OEV}$ & Cretaceous \\
\hline 44 & $\sim \mathrm{N} 070^{\circ}$ & 止? & $?$ & & & Mesozoic metamorphics \\
\hline 46 & $\sim \mathrm{N} 030 * 0$ & $\downarrow /$ & & & & Ophiolite $\cap$ Mesozoic \\
\hline 47 & $\mathrm{~N} 026^{\circ}$ & $\downarrow /$ & & & & Mesozoic \\
\hline 48 & $\sim \mathrm{N} 036^{\circ}, 080^{\circ}$ & $W$ & $\underline{\underline{u}}$ & & & Cretaceous \\
\hline 49 & $\sim \mathrm{N} 050^{\circ}$ & $? \not$ & $\swarrow /$ & & & Plio-Quaternary (?) \\
\hline 20 & $\sim \mathrm{N} 080^{\circ} *$ & $\downarrow$ & $\mathscr{L}$ & & & late Miocene \\
\hline 25 & $\sim \mathrm{N} 015^{\circ} *$ & $\psi$ & $\leq$ & & & Eocene \\
\hline 26 & $\sim \mathrm{N} 065^{\circ}$ & 4 & & & & late Miocene \\
\hline 27 & $\sim \mathrm{N} 045^{\circ}$ & L) & 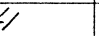 & & & late Miocene \\
\hline 38 & $\mathrm{~N} 060^{\circ} *$ & 4 & 4 & & LIN (1) & Ophiolites \\
\hline 42 & $-\mathrm{N} 070^{\circ}, 015^{\circ}$ & $\leq \quad ?$ & $\downarrow$ & $\Sigma_{c}{ }^{2} \nearrow_{0}$ & $\mathrm{OCV}+\mathrm{OEV}$ & late Miocene \\
\hline 28 & $\sim N 115^{\circ}$ & $\star$ & $\leftrightarrow$ & & LIN (2) & early-middle Miocene \\
\hline 29 & $\mathrm{~N} 036^{\circ}$ & $\downarrow$ & 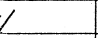 & & & early (?)-middle (?) Miocene \\
\hline 30 & $\sim \mathrm{N} 125^{\circ}$ & $\pi$ & $\leftrightarrow$ & & & Eocene $\cap$ early (?) Miocene \\
\hline 31 & $\sim \mathrm{N} 045^{\circ} *$ & $\pi$ & $\leftarrow$ & & & early-middle Miocene \\
\hline 43 & $-\mathrm{N} 010^{\circ}, 070^{\circ}, 090^{\circ}$ & $\pi \downarrow$ & 5 & & $\mathrm{P}-\mathrm{QF}$ & post-Messinian \\
\hline 50 & $-\mathrm{N} 015^{\circ}$ & $\downarrow /$ & & & & early Miocene \\
\hline $51 \mathrm{E}$ & $-\mathrm{N} 130^{\circ}$ & 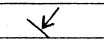 & & & & Eocene \\
\hline $51 \mathrm{M}$ & $\sim \mathrm{N} 110^{\circ}$ & $k$ & & & & early-middle Miocene \\
\hline 41 & $\sim \mathrm{N} 070^{\circ}$ & $\underline{L}$ & $\longleftarrow$ & & $\mathrm{QF}$ & middle Miocene \\
\hline
\end{tabular}


evidence to establish the relative fault-motion chronology along the same fault plane comes from the overprinting of different striations. If we observe on a fault plane the lineation $\mathrm{L}_{2}$ to overprint the lineation $\mathrm{L}_{1}$, we consider $\mathrm{L}_{2}$ to represent a relatively recent fault motion with respect to the motion that created $\mathrm{L}_{1}$. Another criterion to accept that a fault plane has experienced relatively recent displacements is the presence of unconsolidated fault breccia along the fault plane.

Our data collected in the field are represented on maps in the form of fault direction lines, and arrows corresponding to the azimuth of the plunge of the striations (Figs. 2 and 3). The fault direction is the mean azimuth of the main fault system observed in the station. In this study, directions are all clockwise angular values from the north (Table 1). The arrows converging to the fault direction line represent compressive structures, while diverging arrows correspond to extension structures.

We have prepared two maps, one for the relatively 'older' motions (Fig. 2) and another for the 'recent' motions (Fig. 3). In Table 1, we have presented the structural data with the ages of the youngest rocks affected in the measurement station.

\section{Slip motions around the junction}

\subsection{Older motions}

The 'older' fault motions are presented in Fig. 2. The geometry of the folds and fault lineations suggests a tectonic transport oriented north-south, as already noticed by previous workers. Folding and thrusting along the Bitlis Thrust zone (sites 20, 21, 25, 29, 30, 31, $51 \mathrm{E}$ and $51 \mathrm{M}$ ) have accommodated the $\mathrm{N}-\mathrm{S}$ convergence between Eurasian hinterland and the Afro-Arabian foreland.
South of the Bitlis Thrust Zone, the western part of the Amanos Range has suffered left-lateral transpression (sites 50, 43, 47), strike-slipping (sites 17, $18,49)$ or compression (sites 44,48 ). More to the south, NNE-striking transcurrent faulting appears to affect the southwestern sector of the Amanos Range (sites 14, 33, 34, 35, 36). However, in some sites of the latter zone, SW-trending displacements are observed as 'older motions,' along one strike-slip fault (site 37) and two transtensional faults (sites 7, 15). In the southern part of the study area, various fault displacements have been observed. Among them, the approximately $\mathrm{N}$-striking transcurrent faults of the sites 8 and 10 can be interpreted as formed in a N-S crustal convergence zone, but also transtensional motions recorded at sites 2, 5 and 12. The NW-SEoriented compression in site 6 affects only the Eocene and the Langhian rocks. SW-oriented transport as suggested by strike-slip faulting in sites 1 and 16 is also observed in sites $51 \mathrm{E}$ (in Eocene thrusts and overturned folds) and $51 \mathrm{M}$ (in Miocene thrusts). Finally, microtectonic data for the 'older motions' support in majority a $\mathrm{N}-\mathrm{S}$ compression, with local variations.

\subsection{More recent motions}

In some sites (e.g., site 28, 31, and 43 of Fig. 3) along the Bitlis Thrust Zone, a change of tectonic regime is evidenced (1) by the presence of older lineations overprinted by more recent ones (fault plane reactivation) testifying to extensional faulting or (2) by normal faults cutting and offsetting the thrust planes.

Geological mapping (Dubertret, 1955; Ponicarov, 1967) and satellite image analyses (Muehlberger, 1981; Muehlberger and Gordon, 1987) suggest the presence of recent faulting east of the Amanos fault,

\footnotetext{
Note to Table 1:

The youngest rock affected by each event is given in the last column. 'Eocene $\cap$ middle Miocene' denotes the faulted contact between the Eocene and Middle Miocene rocks. Azimuths of fault planes in the second row from left are all clockwise values from the north. Slip-vectors are drawn in the NW or the SW quadrants. In the 'Explanation' column, the type of the field evidence used to establish the relative chronology between the fault movements is given, if this chronology is determined. LIN [2]: lineation overprinting, the following number in brackets indicates the number of observations; T/F: extension vein cut and offset by a fault; F: fault cutting the whole rock mass; OEV: open extension veins; OCV: coexistence of open and closed extension veins, c: closed, o: open veins; P-QF: Plio-Quaternary faulting; QF: Quaternary faulting; AF: active faulting.
} 
with strands parallel to the Amanos structure, and disrupting Plio-Quaternary volcanic rocks. The easternmost of them is named here the Aafrine fault. We have studied a segment of this fault in the Miocene rocks of site 22 (Fig. 3). The $\mathrm{N} 20^{\circ}-35^{\circ}$-striking and steeply dipping fault plane displays subhorizontal slickensides, suggesting strike-slip displacement with left-lateral separation. We have also observed in the site conjugate right-lateral faults trending $\mathrm{N} 128^{\circ}-$ $150^{\circ}$.

Satellite imagery and microtectonic data indicate that fractures in this zone have directions subparalleling either the East Anatolian fault (ca. N 65') or the Amanos fault (ca. $\mathrm{N} \mathrm{30^{ \circ }}$ ). In sites 21 and 23, the orientation of open extension veins suggest, respectively, NNW-SSE- and E-W-trending extension.

E $37^{\circ}$

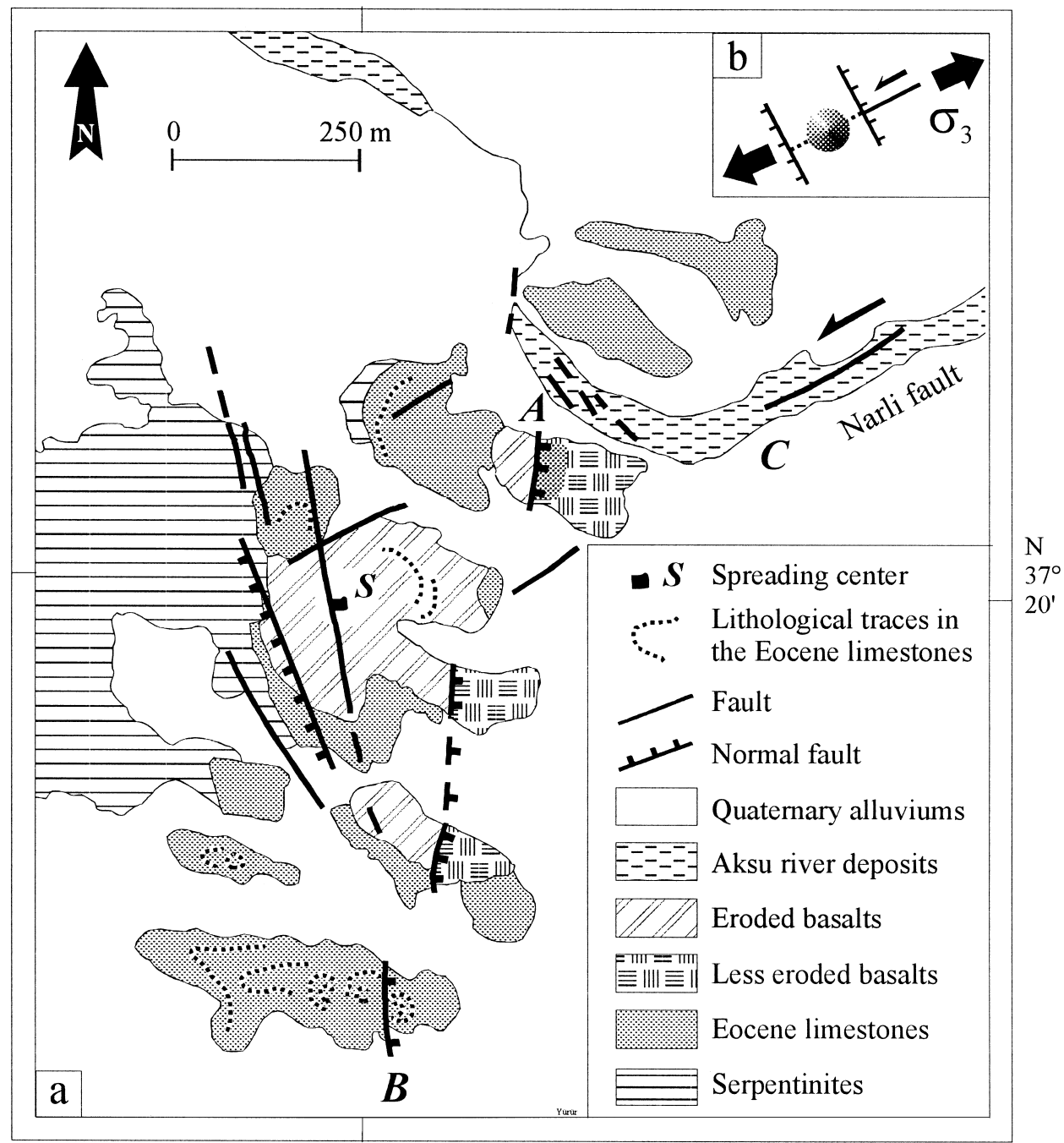

Fig. 4. (a) Geological map showing the Narli volcanism. The map benefited from the interpretation of a multispectral SPOT image (scale: $1 / 100000$, false colours, $K=119, J=275$, acquired on July 14, 1987). (b) Inset picturing the structural interpretation of the Narli volcanism. The concentric circles in between the faults represent the Narli volcano. Strike-slip faulting and opening were associated with E-W-oriented minimum horizontal stress $\sigma_{3}$ and N-S-oriented maximum horizontal stress $\sigma_{1}$. 
This is mechanically compatible with striations trending E-W and ENE-WSW. In site 32, we have studied a fault plane separating Quaternary slope scree from the late Miocene rocks. The fault trends $\mathrm{N} 115^{\circ}$ to $\mathrm{N} 120^{\circ}$. Arpat and Saroglu (1975) and Yalçin (1979) have mapped this structure as a subactive normal fault. The fault plane bears $\mathrm{E}-\mathrm{W}$ lineations attesting for transtension.

East of the junction of the East Anatolian and Amanos faults at Türkoglu (Fig. 1), and in the northern part of the Karasu Basin, we have observed on satellite images straight segments and many irregularities, such as braiding channels, enlarging or narrowing river channels (Aksu river), suggestive of a recent fault zone. One of them, the Narli fault, has been recognised in the field as a recent structure (Yalçin, 1979). At the western termination of this fault, a recent volcanism has developed as suggested by fresh outcrops of basaltic flows (Fig. 4). This structure will be studied in Section 4.

In this zone, we have observed, in a chrome mine gallery opened in the serpentinized ophiolites (site 45, Fig. 3), a fault plane which is known by the miners to have been active during a recent earthquake (pers. comm. in 1990 with Akgün Ilcan and Riza Soypak, responsible engineers of the exploiting company, Güneydogu Krom Isletmeleri, Istanbul). The direction of this active fault is $\mathrm{N} 52^{\circ}$, dipping NW $84^{\circ}$. The pitch of striations is $\mathrm{W} 26^{\circ}$. The left-lateral slip-motion is clearly marked by fault striations on the hanging-wall fault plane. This slipvector of this transtensional fault is oriented $\mathrm{N} 235^{\circ}$.

\section{Volcanism}

\subsection{Relationships with the tectonics}

The comparison of the 'older' and the 'recent' motions indicates that the triple junction zone has first suffered from a N-S compression. This was followed by westward crustal displacements inducing extensional and strike-slip faulting. We interpret that this tectonic regime change near the Maras junction, has developed under the influence of the extrusion movement of the Anatolian block with the formation of the East Anatolian fault.
In this interpretation, the older $\mathrm{N}-\mathrm{S}$ compression has closed all the fractures and prevented the magma from going up to the surface. The more recent extensional and strike-slip faulting has opened the faults and joints to give way up to the magma. This interpretation is coherent with the following volcano-tectonic data.

\subsection{Narli volcanism related to tectonics at local scale}

As pointed out by Çapan et al. (1987), the Karasu valley was a site of volcanic emplacement. In the northern part of this valley, we have observed in a 20-m ground resolution multispectral SPOT image and in the field a small basaltic cone (Narli volcanism, C in Fig. 4a). The cone is located on the flat-lying Eocene marine limestone of the Arabian platform. When the lava cover is thin, near the cone, it is eroded and in places, the underlying white Eocene limestone is easily recognised from the bedding traces, giving an overall light-grey tone. To the east, darker and, consequently, probably thicker volcanic rocks are distinguished in the satellite image. No other volcanic cone can be observed to suggest that the darker volcanic rocks have come out from a different centre. The difference in thickness may be related to erosion across a fault. The boundaries between the darker and lighter basaltic groups form an alignment of rectilinear figures (from ' $A$ ' to ' $B$ ' in Fig. 4). We interpret the alignment as a $\mathrm{N}$-striking fault where the downthrown eastern compartment is relatively less eroded, exposing thicker basalt. A recent left-lateral strike-slip fault, described by Yalçin (1979), is observed in the image west of the Narli cone. Morphologic linears observed in the fluviatile deposits of the Aksu river (' $\mathrm{C}$ ' in Fig. 4) also attest for the recent activity of the Narli fault. In the field, we have observed near the crater of the cone $\mathrm{N}$ $160^{\circ}$-striking extensional fractures attesting for $\mathrm{N}$ $70^{\circ}$-trending extension, compatible with left-lateral displacement along the $\mathrm{N} 60^{\circ}$ Narli fault. Left-lateral displacements along the $\mathrm{N}-\mathrm{S}$ faults are also compatible with the $\mathrm{N} 160^{\circ}$ extensional fractures unless we admit that the compressive strain component is horizontal and trends $\mathrm{N} 160^{\circ}$ (strike-slip regime of deformation). 
In this geometry, the Narli volcano is rooted on $\mathrm{N}$ $160^{\circ}$ extensional fractures, at the extensional junction of the Narli fault with the N-striking faults, both left-lateral. The extensional junction may have provided the distension necessary to generate and conduct the volcanic rocks to the surface (Fig. 4b).

\subsection{Karasu volcanism}

The petrography, geochemistry and radiometric age determination of the volcanic rocks (Karasu unit) along the Amanos fault were carried out by Çapan and coworkers in 1987. $\mathrm{K}-\mathrm{Ar}$ age determinations indicate ages ranging from 2-0.4 Ma (latest Pliocene and Quaternary). The volcanic units were previously mapped by Dubertret $(1955,1962)$ and recognised on the basis of morphological and photogeological studies to be related to the recent tectonic activity (Arpat and Saroglu, 1972). According to the authors, the southern part of the Karasu valley, a narrow structural basin extending east of the Amanos fault, is covered by fissure eruptions and sheet flows of fresh lava of both 'aa' and 'pahoehoe' type. The emission centres are located along NE-trending fissures. Their work shows that the volcanism is formed by a succession (from older to younger) of olivine tholeiite, quartz tholeiite and alkali olivine basalt. Olivine tholeiite is the most abundant type among the seven different lava flows and occupies large areas along the valley floor. The quartz tholeiite and alkali olivine basalt is located all along the western margin of the valley.

The older olivine tholeiite of the valley floor is vesicular, olivine- and hypersthene-normative basalt. The subsequently erupted quartz tholeiite is slightly quartz-normative and forms blocky laves interlayered with brecciated agglomerate. It contains large plagioclase laths, olivine and a few clinopyroxene phenocrysts. Its groundmass is composed of plagioclase microlites, olivine, opaque minerals and interstitial volcanic glass. The more recent alkali olivine basalt, with the exception of the Ceylanli flow dated as $1.73 \pm 0.10 \mathrm{Ma}$, covers a west-wall fault system that had cut through the previous quartz tholeiitic basalt. Large olivine crystals with a few plagioclase $\left(\mathrm{An}_{53}\right)$ form the main phenocryst assemblage, while the matrix is mostly plagioclase microlites, olivine and opaque mineral grains in an interstitial volcanic glass. It is olivine- and nepheline-normative basalt.
We point out some conclusions of Çapan et al. (1987): (1) Complicated block movements have taken place along the Karasu valley, leading to NE-trending tensional fractures which might represent channels for outpouring of the basalt. (2) The Qz tholeiite series have been contaminated by crustal material, while the younger alkali olivine basalt series is the product of a more depleted source, but both fall on to the mantle array. (3) The alkali basalt was transferred more rapidly to the surface and this may be due to a transitory behaviour of the fault in an extension regime. These conclusions are coherent with our observation of a later extensional event related with the occurrence of the uppermost Pliocene-Quaternary volcanism.

\subsection{How the Amanos fault kinematics have changed}

The 'older motions' characterised by a N-Strending compression can be related to plate collision occurring since the middle Miocene between the northern margin of Africa/Arabia with the southern margin of Eurasia (e.g., Yilmaz et al., 1988; Chorowicz et al., 1994). This convergent phase was accompanied later by the westward expulsion of the Anatolian block (Sengör et al., 1985; Dewey et al., 1986), accommodated by the East Anatolian fault.

In the triple junction area, there are field evidences that the East Anatolian fault cuts and offsets the thrust surfaces formed during the compression (Yalçin, 1979; Perinçek and Çemen, 1990; Yürür, 1992; Chorowicz et al., 1994). Moreover, McKenzie (1976) proposed that the East Anatolian fault cuts also the Amanos fault zone (prolongation of the Dead Sea transform) at Türkoglu (' $T$ ' in Fig. 1) and extends south westwards through the Amanos Range. However, on the basis of $20 \mathrm{~m}$ multispectral and 10 $\mathrm{m}$ panchromatic SPOT image interpretations and field observations, Yürür (1992) and Chorowicz et al. (1994) have shown that at Türkoglu, the East Anatolian fault does not traverse the Amanos fault. For this reason, we propose that the Amanos range, which once indented southern Anatolia, should in the present-day situation be attached to the extruded Anatolian block. Another argument is that the Amanos Range should move with a westerly component in order to open the Quaternary Karasu basin, located east of the range. This change of kinematics is 


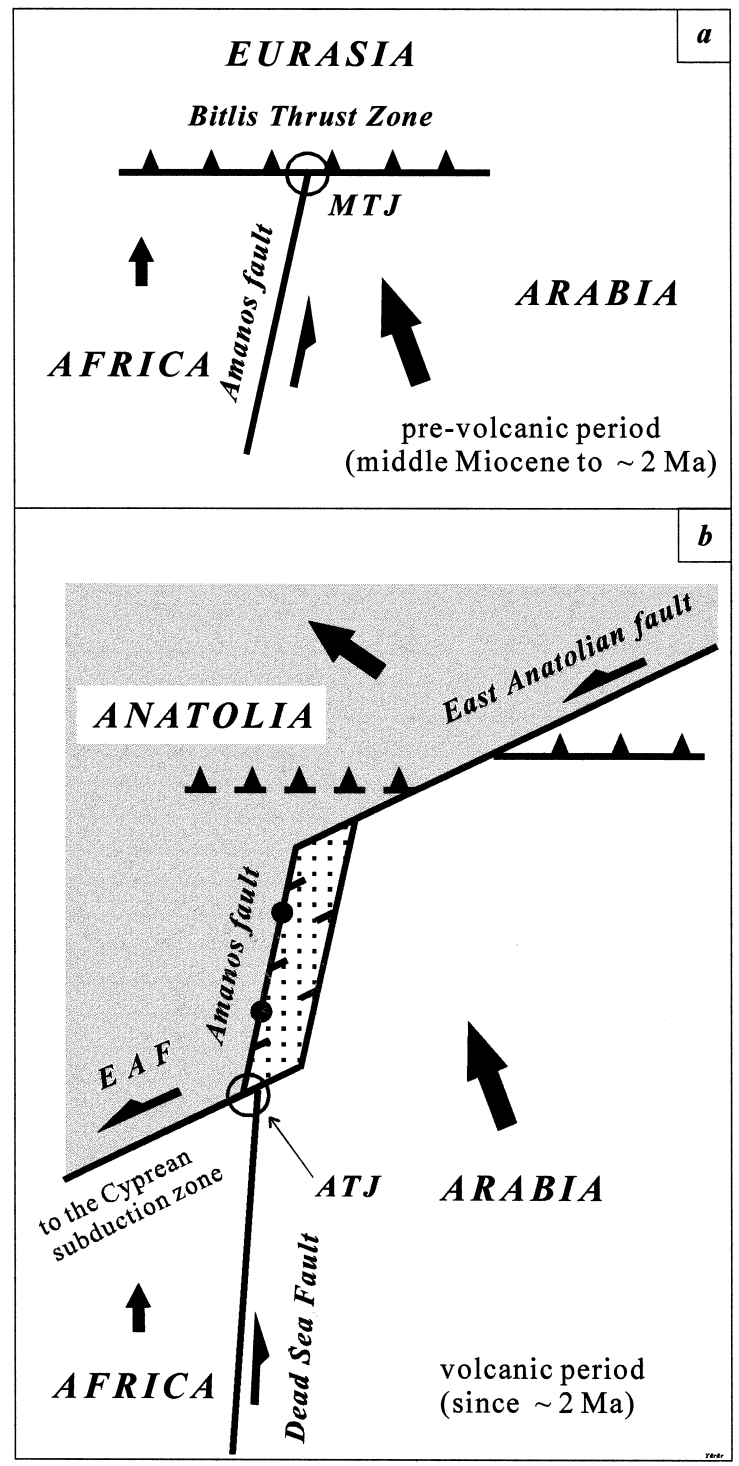

Fig. 5. Tectonic evolution of the studied area. (a) Formation of the Maras triple junction in the middle-late Miocene. (b) Change of tectonic regime near Maras at around 2 Ma. ATJ: Antakya Triple Junction; EAF: East Anatolian fault; MTJ: Maras Triple Junction. The heavy black lines are the major faults. Arrows near the faults show the slip sense. Thrusts are drawn with black triangles on the upper block. The stippled area is the Karasu Basin, black circles schematically indicating the fissural Karasu volcanism. The heavy black arrows are the slip vectors of plate motions relative to Eurasia, drawn using the results of Fig. 6. The shaded area represents the Anatolian block. The major structures of the Narli volcanism are pictured in the great circle. schematically illustrated in Fig. 5. The Amanos segment of the Dead Sea transform fault zone may once have accommodated by compression, transpression and strike-slipping the regional $\mathrm{N}-\mathrm{S}$ convergence (Fig. 5a), as suggested by our slip-vectors of the older motions (Fig. 2). Later and probably around 2 $\mathrm{Ma}$, the westward extrusion of the Anatolian block, related to the formation of the East Anatolian fault, have changed the deformation pattern in the Amanos region (Fig. 5b), inducing E-W-oriented extension (Fig. 3) and the opening of the Karasu basin.

The still continuing $\mathrm{N}$ - to $\mathrm{NNW}$-ward motion of Arabia relative to Africa and Anatolia, combined with westward motion of Anatolia-Amanos, has resulted in oblique extension along the Amanos fault and NE-striking extension fractures formed in the Karasu basin along the west wall. The volcanism has poured out from the extensional fissures. We consequently interpret that the volcanism is coeval with the East Anatolian fault formation.

We shall check this interpretation in Section 5 where plate kinematics will be presented briefly with the aim of computing the initiation age of the East Anatolian fault.

\section{Plate kinematics}

We have constructed a plate velocity diagram for a point located near Maras, $37^{\circ} 30^{\prime} \mathrm{N}, 37^{\circ} \mathrm{E}$, in order to compute the horizontal slip rate along the East Anatolian fault and, consequently, estimate its initiation age (Fig. 6). Parameters of the kinematics parameters are given in Table 2.

The continuous lines of Fig. 6 are drawn using the AF/EU datum (DeMets et al., 1990) and the instantaneous motions obtained from the space geodetic measurements (Le Pichon et al., 1995). The dashed lines correspond to $\mathrm{AR} / \mathrm{EU}$ and $\mathrm{AR} / \mathrm{AF}$ velocity vectors computed using the poles of rotation of DeMets et al. (1990). The two AR/EU velocity vectors are very close in orientation $\left(154^{\circ}\right.$ and $\left.157^{\circ}\right)$, but the slip rate is 15 and $26 \mathrm{~mm} /$ year. The true value may be closer to the maximal value (pers. comm. of Dr. Aykut Barka, 1997). The diagram yields a slip rate of $7.8-9 \mathrm{~mm} /$ year along the East Anatolian fault. This slip rate is slightly higher than $6 \mathrm{~mm} /$ year (Kiratzi, 1993), but fairly smaller than 


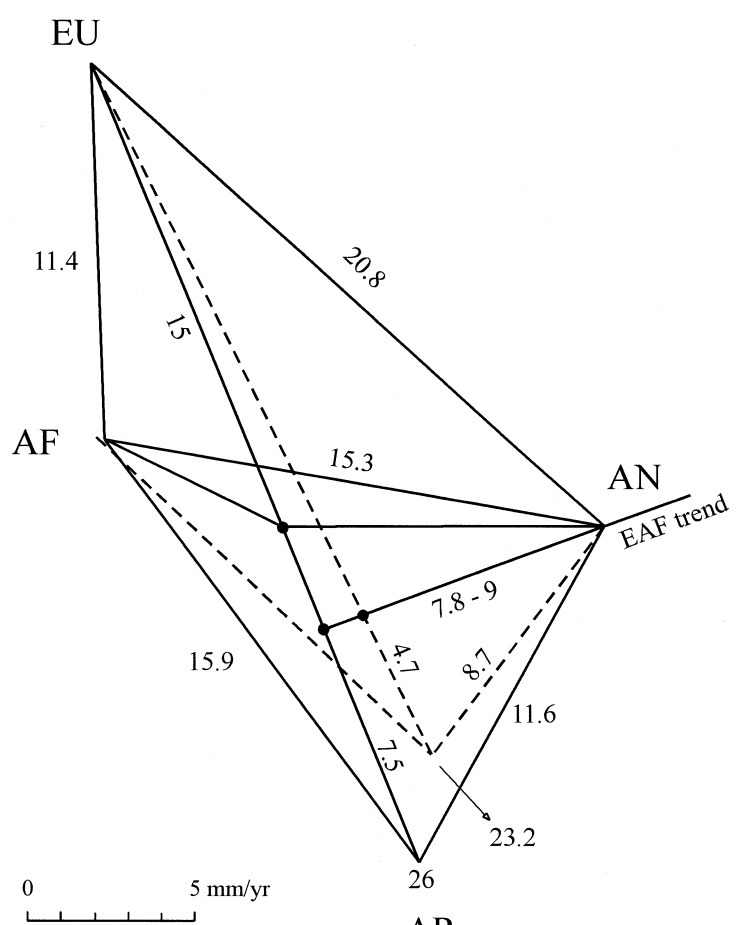

AR

Fig. 6. Velocity diagram of relative plate motions near Maras $\left(37^{\circ} 30^{\prime} \mathrm{N}, 37^{\circ} \mathrm{E}\right)$. Kinematic parameters are given in Table 2. $\mathrm{AF} / \mathrm{EU}$ vector is computed from DeMets et al. (1990); EU/AN and EU/AR vectors are computed from Le Pichon et al. (1995). Dashed lines were obtained using the AR/EU rotation pole of DeMets et al. (1990). 'EAF trend' is the orientation of the East Anatolian fault.

$29 \mathrm{~mm} /$ year (Taymaz et al., 1991), both values being computed from seismic data. It is also smaller than the $19 \mathrm{~mm} /$ year slip rate computed by Lyberis et al. (1992) on the basis of the analysis of the kinematics assuming a 13-Ma age for the initiation of the Anatolian extrusion and of the East Anatolian fault.

Some strike-slipping motion between Arabia and Anatolia has been taken up along several faults (Kempler and Garfunkel, 1994), including our sites 24 and 41 (Fig. 3). However, these structures are not as continuous as the East Anatolian fault, and the minimum slip rate we have found for the East Anatolian fault $(7.8 \mathrm{~mm} /$ year $)$ would not be notably modified.

Arpat and Saroglu (1972, 1975) have first proposed for the East Anatolian fault a total displacement of $27 \mathrm{~km}$. Detailed field work (Herece and Akay, 1992) has indicated that this amount is not greater than $15 \mathrm{~km}$ and that the initiation age of the fault may be late Pliocene, even Quaternary (pers. comm. of Dr. Ergün Akay). Using the $15 \mathrm{~km}$ of total displacement and the $7.8 \mathrm{~mm} /$ year value, we have found a maximum initiation age at 1.9 Ma for the East Anatolian fault. This age is in good agreement with the late Pliocene-Quaternary age found by Herece and Akay (1992). Higher slip rates (i.e., 9 $\mathrm{mm} /$ year) would result in smaller initiation ages. However, this 1.9-Ma age could be slightly higher when considering that several EAF-type faults located south of the EAF also accommodate some part

Table 2

Parameters of the plate kinematic analysis

\begin{tabular}{|c|c|c|c|c|c|}
\hline \multirow[t]{2}{*}{ Plate pair } & \multirow{2}{*}{$\begin{array}{l}\text { Latitude } \\
\left({ }^{\circ} \mathrm{N}\right)\end{array}$} & \multirow{2}{*}{$\begin{array}{l}\text { Longitude } \\
\left({ }^{\circ} \mathrm{E}\right)\end{array}$} & \multirow{2}{*}{$\begin{array}{l}\omega \\
\left({ }^{\circ} / \mathrm{Ma}\right)\end{array}$} & \multicolumn{2}{|c|}{ Motion near Maras $\left(37.5^{\circ} \mathrm{N}, 37^{\circ} \mathrm{E}\right)$} \\
\hline & & & & Azimuth $\left(^{\circ}\right)$ & Velocity $(\mathrm{mm} / \mathrm{yr})$ \\
\hline $\mathrm{AF} / \mathrm{EU}^{1}$ & 21.0 & -20.6 & 0.13 & 178 & 11.4 \\
\hline $\mathrm{AN} / \mathrm{EU}^{2}$ & 32.73 & 32.03 & 1.72 & 132 & 20.8 \\
\hline $\mathrm{AR} / \mathrm{EU}^{2}$ & - & - & - & 157 & $15-26$ \\
\hline $\mathrm{AR} / \mathrm{EU}^{1}$ & 24.6 & 13.7 & 0.52 & 154 & 23.2 \\
\hline $\mathrm{AR} / \mathrm{AF}^{3}$ & - & - & - & $116-143$ & $6.3-15.9$ \\
\hline $\mathrm{AR} / \mathrm{AF}^{1}$ & 24.1 & 24.0 & 0.42 & 133 & 13.9 \\
\hline $\mathrm{AR} / \mathrm{AN}^{3}$ & - & - & - & 29 & 11.6 \\
\hline $\mathrm{AN} / \mathrm{AF}^{3}$ & - & - & - & 100 & 15.3 \\
\hline
\end{tabular}

\footnotetext{
${ }^{1}$ Velocity due to rotation about a pole (DeMets et al., 1990).

${ }^{2}$ Space geodetic data (Le Pichon et al., 1995).

${ }^{3}$ Measured on the velocity diagram.

$\omega$, rotation angle of the first plate relative to the second is positive if the rotation is counterclockwise.
} 
of the Anatolian motion. This age becomes close to 2 Ma, the initiation age of the Karasu volcanic activity along the Amanos fault.

\section{Discussion and conclusions}

Our main observation is the change from an older deformation pattern characterised by a regional $\mathrm{N}-\mathrm{S}$ compression associated to $\mathrm{N}-\mathrm{S}$-trending slip vectors (Fig. 2), to a more recent $\mathrm{E}-\mathrm{W}$ extension associated to predominantly E-W-oriented slip vectors (Fig. 3). The first event (Fig. 5a) is an intercontinental collision between Eurasia and Africa/Arabia. The second event (Fig. 5b) is, in the frame of this continuing collision, the separation and westward extrusion of the Anatolian block squeezed between Eurasia and Arabia.

We interpret that the genesis of the Karasu volcanism is closely related to the change of deformation pattern, especially along the Amanos fault. The Amanos fault has first accommodated the relative plate motion between Africa and Arabia as a transpressive fault. The displacement has switched to transtension as a result of the lateral movements induced to the Amanos fault plane by the westward extrusion of the Anatolian block along the East Anatolian fault. This change of kinematics along the Amanos fault may have occurred at ca. $2 \mathrm{Ma}$, when the Karasu volcanic activity started along the fault. According to the petrography and geochemistry data, the Karasu volcanic rocks are slightly contaminated and most probably of mantle origin. The lithospheric nature of the Amanos fault as a segment of the Dead Sea Transform fault zone, together with the recent tension along the fault plane, have played important roles in the generation of the Karasu volcanism. Tension has resulted in decompression of the lithospheric mantle along deep parts of the Amanos fault, generating the Karasu magma which has reached the surface using the fault plane and extension fractures. The magma transfer, starting at ca. $2 \mathrm{Ma}$ with the older olivine tholeiite, accelerated with time when the later alkali basalt outpoured.

This interpretation implies that, in the studied area, the lateral extrusion of Anatolia, together with the tectonic activity along the East Anatolian fault, started at ca. 2 Ma. This age is coherent with biblio- graphic data and our new computation of the rate of displacement $(7.8 \mathrm{~mm} /$ year) along the East Anatolian fault.

Our analysis of the kinematics also suggests a NNW-trending Arabian plate motion relative to Eurasia (Fig. 6), subparallel to $\mathrm{N} 160^{\circ}$-striking shortening-parallel crustal extension fractures in the Arabian platform. These fractures might have initiated during the continuing collision with Eurasia. The deformation at the junction of these deep fractures with the Narli strike-slip fault may have served to create the necessary distension to generate a magma and bring it to the surface. We have put the Narli volcano formation in the post-2 Ma period (Fig. 5b) assuming that this activity, located in the Karasu basin, is contemporaneous with the Karasu volcanism. However, we have no evidence to support this, and the Narli activity may well have taken place before the emplacement of the Karasu volcanic rocks.

As suggested by Perinçek and Çemen (1990), it is possible to regard the formation of the Karasu Basin as resulting from left-stepping offset along the southern margin of the Anatolian block, in between the East Anatolian fault and the Cyprean subduction zone (Fig. 5b). The Karasu volcanic activity took place mainly in the $\mathrm{W}$-margin of the basin. The Karasu Basin ends southwards into a geometrically complex Amik Basin (Fig. 1), not drawn in Fig. 5b. Our geodynamic model of Fig. 5b suggests the migration of the triple junction from Maras to south, near Antakya. The complexity of the Amik Basin is perhaps due to its location near the recent triple junction, where the Dead Sea Fault system terminates against the East Anatolian Fault zone.

\section{Acknowledgements}

The first author wishes to express his gratitude to Prof. M. Niyazi Gundogdu, Prof. A.M. Celal Sengor and Prof. Nicolas Lyberis, who gave him the possibility to learn much about plate tectonics, and satellite image/field characteristics of the continental deformation zones. The manuscript benefited very much from the critics formulated by two anonymous reviewers. The field work was financially supported by the French Embassy of Ankara and Hacettepe University. 


\section{References}

Arpat, E., Saroglu, F., 1972. The East Anatolian fault System: thoughts on its development. Bull. Miner. Res. Explor. Inst., Ankara 78, 33-39.

Arpat, E., Saroglu, F., 1975. On some important young tectonic events in Turkey. Bull. Miner. Res. Explor. Inst., Ankara 18, 91-110, in Turkish.

Barka, A.A., Kadinsky-Cade, K., 1988. Strike-slip fault geometry in Turkey and its influence on earthquake activity. Tectonics 7 (3), 663-684.

Chorowicz, J., Luxey, P., Lyberis, N., Carvalho, J., Parrot, J.-F., Yürür, T., Gündogdu, M.N., 1994. The Maras Triple Junction (southern Turkey) based on digital elevation model and satellite imagery interpretation. J. Geophys. Res. 99 (B10), 2022520242.

Chorowicz, J., Koffi, B., Chalah, C., Chotin, P., Collet, B., Poli, J.-T., Rudant, J.-P., Sykioti, O., Vargas, G., 1995. Possibilités et limites de l'interprétation géologique des images (SAR) ERS-1. Bull. Soc. Fr. Photogramm. Télédétection 138 (2), 82-95.

Çapan, U.Z., Vidal, P., Cantagrel, J.M., 1987. K-Ar, Nd, Sr and $\mathrm{Pb}$ isotopic study of Quaternary volcanism in Karasu Valley (Hatay), N-end of Dead Sea Rift zone in SE Turkey. Yerbilimleri, Bull. Earth Sci. Center, Hacettepe Univ., Ankara 14, $165-178$

DeMets, C., Gordon, R.G., Argus, D.F., Stein, S., 1990. Current plate motions. Geophys. J. Int. 101, 425-478.

Dewey, J.F., Pitman, W.C., Ryan, W.B.F., Bonin, J., 1973. Plate tectonics and the evolution of the Alpine system. Bull. Geol. Soc. Am. 84, 3137-3180.

Dewey, J.F., Hempton, M.R., Kidd, W.S.F, Saroglu, F., Sengör, A.M.C., 1986. Shortening of continental lithosphere: the neotectonics of Eastern Anatolia-a young collision zone. In: Coward, M.P., Ries, A.C. (Eds.), Collision Tectonics. Geol. Soc. London, Spec. Publ. 19, 3-36.

Dubertret, L., 1955. Géologie des roches vertes du Nord-Ouest de la Syrie et du Hatay (Turquie), Notes et Mémoires sur le Moyen-Orient, t. VI: 1-224.

Dubertret, L., 1962. Carte géologique du Liban, Syrie et bordure des pays voisins, échelle $1 / 1000000^{\mathrm{e}}$. I.G.N., Paris.

Gülen, L., Barka, A., Toksöz, M.N., 1987. Continental collision and related complex deformation: Maras triple junction and surrounding structures. Yerbilimleri, Bull. Earth Sci. Center, Hacettepe Univ., Ankara 14, 319-336, in Turkish, with English abstract.

Herece, E., Akay, E., 1992. The East Anatolian fault between Karliova and Çelikhan. Proc. 9th Petroleum Congress. Chamber of Pet. Eng. and Turk. Assoc. of Pet. Geol., Ankara., pp. 361-372., in Turkish.

Jackson, J.A., McKenzie, D.P., 1984. Active tectonics of the Alpine-Himalayan belt between western Turkey and Pakistan. Geophys. J. R. Astron. Soc. 77, 185-264.

Jackson, J.A., McKenzie, D.P., 1988. The relationship between plate motions and seismic moment tensors, and the rates of active deformation in the Mediterranean and Middle East. Geophys. J. 93, 45-73.
Karig, D.E., Kozlu, H., 1990. Late Palaeogene-Neogene evolution of the triple junction near Maras, south-central Turkey. J. Geol. Soc. London 147, 1023-1034.

Kelling, G., Gökçen, S.L., Floyd, P.A., Gökçen, N., 1987. Neogene tectonics and plate convergence in the eastern Mediterranean: new data from southern Turkey. Geology 15, 425-429.

Kempler, D., Garfunkel, Z., 1994. Structures and kinematics in the northeastern Mediterranean: a study of an irregular plate boundary. Tectonophysics 234, 19-32.

Kiratzi, A.A., 1993. A study on the active crustal deformation of the North and East Anatolian fault zones. Tectonophysics 225, 191-203.

Le Pichon, X., Angelier, J., 1979. The Hellenic arc and trench system: a key to the neotectonic evolution of the eastern Mediterranean Sea. Tectonophysics 60, 1-42.

Le Pichon, X., Gaulier, J.-M., 1988. The rotation of Arabia and the Levant fault system. In: Le Pichon, X., Cochran, J.R. (Eds.), The Gulf of Suez and Red Sea Rifting. Tectonophysics 153, 271-294.

Le Pichon, X., Chamot-Rooke, N., Lallemant, S., Noomen, R., Veis, G., 1995. Geodetic determination of the kinematics of central Greece with respect to Europe: implications for Eastern Mediterranean tectonics. J. Geophys. Res. 100 (B7), 1267512690.

Lyberis, N., Yürür, T., Chorowicz, J., Kasapoglu, E., Gündogdu, N., 1992. The East Anatolian fault: an oblique collisional belt. Tectonophysics 204, 1-15.

McKenzie, D.P., 1970. Plate tectonics of the Mediterranean Region. Nature 226, 239-248.

McKenzie, D.P., 1972. Active tectonics of the Mediterranean region. Geophys. J. R. Astron. Soc. 30, 109-185.

McKenzie, D.P., 1976. The East Anatolian fault: a major structure in the Eastern Turkey. Earth Planet. Sci. Lett. 29, 189-193.

MTA, 1962a. Geological map of Turkey, scale 1/500000, Hatay sheet. MTA (Ins. of Min. Res. Explor.), Ankara.

MTA, 1962b. Geological map of Turkey, scale 1/500000, Adana sheet. MTA (Ins. of Min. Res. and Explor.), Ankara.

Muehlberger, W.R., 1981. The splintering of the Dead Sea fault zone in Turkey. Yerbilimleri, Bull. Earth Sci. Center, Hacettepe Univ., Ankara 8, 123-130.

Muehlberger, W.R., Gordon, M.B., 1987. Observations on the complexity of the East Anatolian Fault, Turkey. J. Struct. Geol. 9 (7), 899-903.

Oral, M.B., Reilinger, R., Toksöz, M.N., King, R.W., Barka, A.A., Lenk, O., 1994. GPS measurements of crustal deformation in Turkey (1988-1992): coherent rotation of the Anatolian plate, Abstract. Eos Trans., AGU, 75(16), Spring Meeting Suppl., 116.

Perinçek, D., 1979. Geological investigation of the ÇelikhanSincik-Koçali area (Adiyaman Province), Ist. Üniv. Fen Fak. Mec., Istanbul, Serie B44, 127-147.

Perinçek, D., Çemen, I., 1990. The structural relationship between the East Anatolian and Dead Sea fault zones in southeastern Turkey. Tectonophysics 172, 331-340.

Perinçek, D., Günay, Y., Kozlu, H., 1987. New observations on strike-slip-slip faults in east and southeast Anatolia. Proc. 7th Biannual Petroleum Congress of Turkey, Chamber of Pet. 
Eng. and Turk. Assoc. of Pet. Geol. Ankara, pp. 89-103, in Turkish.

Ponicarov, V.P. (editor-in-chief), 1967. The geological map of Syria, Explanatory notes: I. Stratigraphy, Igneous rocks and Tectonics, with geological maps at scale 1/500000. V.O. Technoexport, Moscow, $230 \mathrm{pp}$.

Seymen, I., Aydin, A., 1972. The Bingöl Earthquake fault and its relation to the North Anatolian fault zone. Bull. Miner. Res. Explor. Inst., Ankara 79, 1-8.

Sengör, A.M.C., 1979. The North Anatolian transform fault: its age, offset and tectonic significance. J. Geol. Soc. London 136, 269-282.

Sengör, A.M.C., Görür, N., Saroglu, F., 1985. Strike-slip-slip faulting and related basin formation in zones of tectonic escape: Turkey as a case study. In: Biddle, T.R., Christie-Blick
(Eds.), Strike-slip-slip Deformation, Basin Formation and Sedimentation. Soc. Econ. Palaeontol. Miner., Spec. Publ. 37, 227-264.

Yalçin, N., 1979. Characters of the East Anatolian fault between Türkoglu and Karaagaç (K. Maras) in relation to settlement problems. Bull. Geol. Soc. Doc., Turkey 9, 49-55, in Turkish, abstract in English.

Yilmaz, Y., Gürpinar, O., Yigitbas, E., 1988. Tectonic evolution of the Miocene Basins at the Amanos mountains and the Maras region. Turkish Assoc. Pet. Geol. 1 (1), 52-72, Ankara; in Turkish, abstract in English.

Yürür, T., 1992. La jonction de la faille du Levant avec la chaîne $\mathrm{du}$ Taurus oriental. Unpublished $\mathrm{PhD}$ Thesis, no. 92-32. Académie de Paris, Univ. Pierre et Marie Curie, 120 p. 